\title{
Management of acute otitis media
}

\author{
S Forgie, G Zhanel, J Robinson; Canadian Paediatric Society, Infectious Diseases and \\ Immunization Committee
}

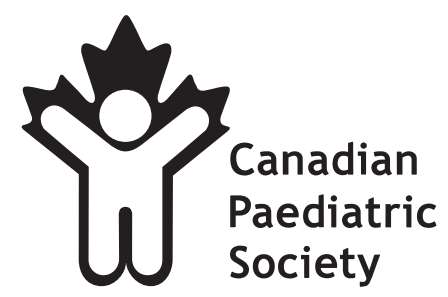

$\mathrm{T}$

he present position statement updates a previous document released in 1998 (1). It is based on published evidence, and is intended to be a guide for sound clinical decision making. The present document is not intended for children with craniofacial abnormalities, immunocompromising conditions or complicated acute otitis media (AOM), or newborns younger than eight weeks of age.

\section{WHY DO CHILDREN GET AOM?}

AOM is extremely common in children - in fact, $75 \%$ of children have at least one episode by one year of age (2). The primary defect leading to AOM is eustachian tube dysfunction and obstruction. Compared with adults, children are predisposed to $\mathrm{AOM}$ because their eustachian tubes are shorter, more horizontal and more prone to obstruction by enlarged adenoids $(3,4)$. Furthermore, viral infections and allergies are common in young children, and both can cause eustachian tube inflammation $(5,6)$. Finally, children (especially those with recurrent otitis media) may have decreased levels of secretory immunoglobulin A - an antibody that decreases bacterial adherence in the nasopharynx (7).

Once the eustachian tube is obstructed, two things happen. First, mucociliary clearance is impaired, trapping mucus in the middle ear space (8). Second, resorption of gases within the middle ear space creates a pressure differential, akin to a vacuum, which pulls bacteria from the nasopharynx into the middle ear space. Once introduced into this space, bacteria can proliferate and may cause a secondary infection. Thus, it is rare to develop AOM without an antecedent viral upper respiratory tract infection, with $\mathrm{AOM}$ typically developing after several days of viral symptoms.

\section{ARE CERTAIN CHILDREN AT HIGHER RISK FOR AOM?}

The major risk factors for AOM are young age and daycare attendance. The former is likely related to the anatomy of the eustachian tube and low secretory immunoglobulin A levels, while the latter is related to increased exposures to viral infections, coupled with an increased incidence of nasopharyngeal colonization with pathogenic bacteria. Other risk factors include orofacial abnormalities (such as cleft palate), household crowding, exposure to cigarette smoke, premature birth, not being breastfed, immunodefi- ciency and a positive family history of otitis media $(9,10)$. Children of First Nations or Inuit ethnicity are also at higher risk for AOM (11).

\section{HOW SHOULD ONE DIAGNOSE AOM?}

To properly diagnose AOM, there must be fluid behind the tympanic membrane (a middle ear effusion) and specific signs and symptoms of middle ear inflammation (Table 1) $(12-22)$ - indicating that this fluid is pus.

If $\mathrm{AOM}$ is diagnosed based on the criteria in Table 1 , is antimicrobial treatment indicated?

Understanding the etiology of acute middle ear effusion and inflammation is the key to answering this question. Viruses play an important role in the pathogenesis of $\mathrm{AOM}$ and may be a direct cause of spontaneously resolving AOM, because they have been found in middle ear fluid in the absence of bacteria (23). However, studies $(24,25)$ using tympanocentesis show bacteria are present most of the time. The strains of bacteria have changed over time. Before the introduction of the pneumococcal conjugate vaccine, the most common bacteria isolated from AOM were Streptococcus pneumoniae (median 42\% of cases), Haemophilus influenzae (median 31\% of cases) and Moraxella catarrhalis (median $16 \%$ of cases) (26). Other bacteria such as group A streptococci and Staphylococcus aureus were rare, as were polymicrobial infections $(27,28)$. After the introduction of the conjugated pneumococcal vaccine, American studies assessed bacterial isolates from vaccinated children younger than two years of age with severe or refractory AOM. They found that the proportion of AOM cases caused by $S$ pneumoniae decreased from $48 \%$ to $31 \%$ and the proportion of cases caused by nontypeable $H$ influenzae increased from $41 \%$ to $56 \%(29-31)$.

Several meta-analyses (32-34) have examined the role of antimicrobials in the treatment of AOM. As one might predict for what is primarily a bacterial infection, the cumulative evidence demonstrates more rapid resolution of symptoms with the use of antimicrobials. However, the treatment effect for antimicrobials is small - approximately 15 children have to be treated for one child to have resolution of symptoms (clinical cure) at $48 \mathrm{~h}$ (32). There have been criticisms of the studies that led to this conclusion $(35,36)$. First, in most of the studies, the diagnosis of AOM was

Correspondence: Canadian Paediatric Society, 2305 St Laurent Boulevard, Ottawa, Ontario K1G 4J8. Telephone 613-526-9397,

fax 613-526-3332, Web sites www.cps.ca, www.caringforkids.cps.ca 


\section{TABLE 1}

\section{The signs or symptoms that must be present to make a} diagnosis of acute otitis media

\section{Signs of a middle ear effusion:}

- An immobile tympanic membrane (as demonstrated by pneumatic insufflation, tympanogram or acoustic reflectometry) or presence of liquid in the external ear canal as a result of tympanic membrane rupture (acute otorrhea)

- + /- Opacification of the tympanic membrane (not secondary to scarring)

- +/- Loss of the bony landmarks behind the tympanic membrane (specifically loss of the short or lateral process of the malleus)

- + - A visible air fluid level behind the tympanic membrane

Signs of middle ear inflammation:

- Bulging tympanic membrane with marked discolouration (hemorrhagic, red, gray or yellow)

Acute onset of symptoms:

- Rapid onset of ear pain (otalgia), or unexplained irritability in a preverbal child

Data are adapted from references 12 to 22

\section{TABLE 2}

\section{Watchful waiting approach}

Observation for $48 \mathrm{~h}$ to $72 \mathrm{~h}$ without antimicrobial agents is appropriate in the following instances:

- The child is older than six months of age

- The child does not have immunodeficiency, chronic cardiac or pulmonary disease, anatomical abnormalities of the head or neck, or a history of complicated otitis media (otitis media accompanied by suppurative complications or chronic perforation), or Down syndrome

- The illness is not severe - otalgia appears to be mild and fever is lower than $39^{\circ} \mathrm{C}$ in the absence of antipyretics

- Parents are capable of recognizing signs of worsening illness and can readily access medical care if the child does not improve

If the child's status worsens or does not improve during the observation period, and the primary diagnosis still appears to be acute otitis media, antimicrobial therapy must be started

made clinically, which suggests the possibility of a misdiagnosis, but the same applies to diagnosing AOM in Canadian children today. Second, clinical cure rather than bacteriological cure was chosen as the primary outcome because of the difficulty of performing tympanocentesis initially and at follow-up. Children with early bacteriological cure are at lower risk of early recurrence of AOM with the same organism, but it appears that approximately five children need to achieve bacteriological cure to prevent one recurrence (37). Finally, a placebo was not always administered to the control group. Despite these criticisms, spontaneous resolution occurs in most cases. Not all children with AOM should receive immediate treatment with antimicrobials, and a watchful waiting approach with analgesia can be used in many cases.

\section{WHEN IS IT APPROPRIATE TO ADOPT A WATCHFUL WAITING APPROACH?}

If the child is older than six months of age with mild signs and symptoms, observation without the use of antimicrobials for $48 \mathrm{~h}$ to $72 \mathrm{~h}$ may be an option if follow-up can be assured (Table 2, Figure 1) $(38,39)$. Six months was chosen

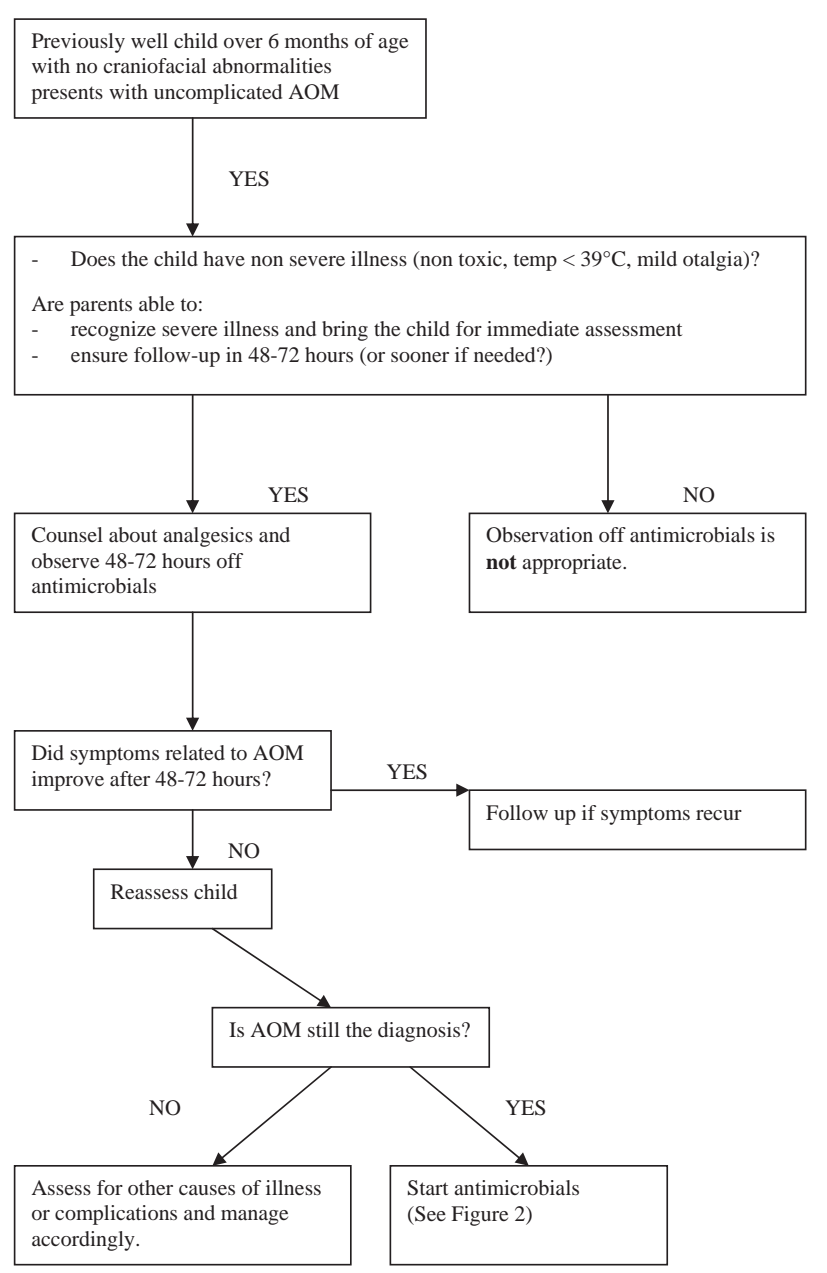

Figure 1) Flow chart of the watchful waiting approach to acute otitis media (AOM)

as the lower age limit because there are limited data on this approach in younger children and severe illness is more difficult to recognize $(40,41)$. If the watchful waiting approach is used, it is vital to provide appropriate advice about analgesics, with acetaminophen or ibuprofen being the usual choices. It is recommended to either have the family return if the child does not improve or to provide a prescription for antimicrobials that can be filled at the parents' discretion (deferred prescription). Studies $(42,43)$ have shown that although symptom resolution may take slightly longer with a watchful waiting approach, parents are generally satisfied with this option, and only approximately one-third of those children eventually receive antimicrobials.

The watchful waiting option is not appropriate for children who have severe symptoms (appear toxic, have severe otalgia and/or high fever [greater than $39^{\circ} \mathrm{C}$, orally]) (44). Aboriginal children have been found to have a high incidence of chronic suppurative otitis media, but it is not known whether a watchful waiting approach in these children increases the risk of this complication $(11,45)$. Nonetheless, it would seem prudent to prescribe antimicrobials sooner to Aboriginal children. 


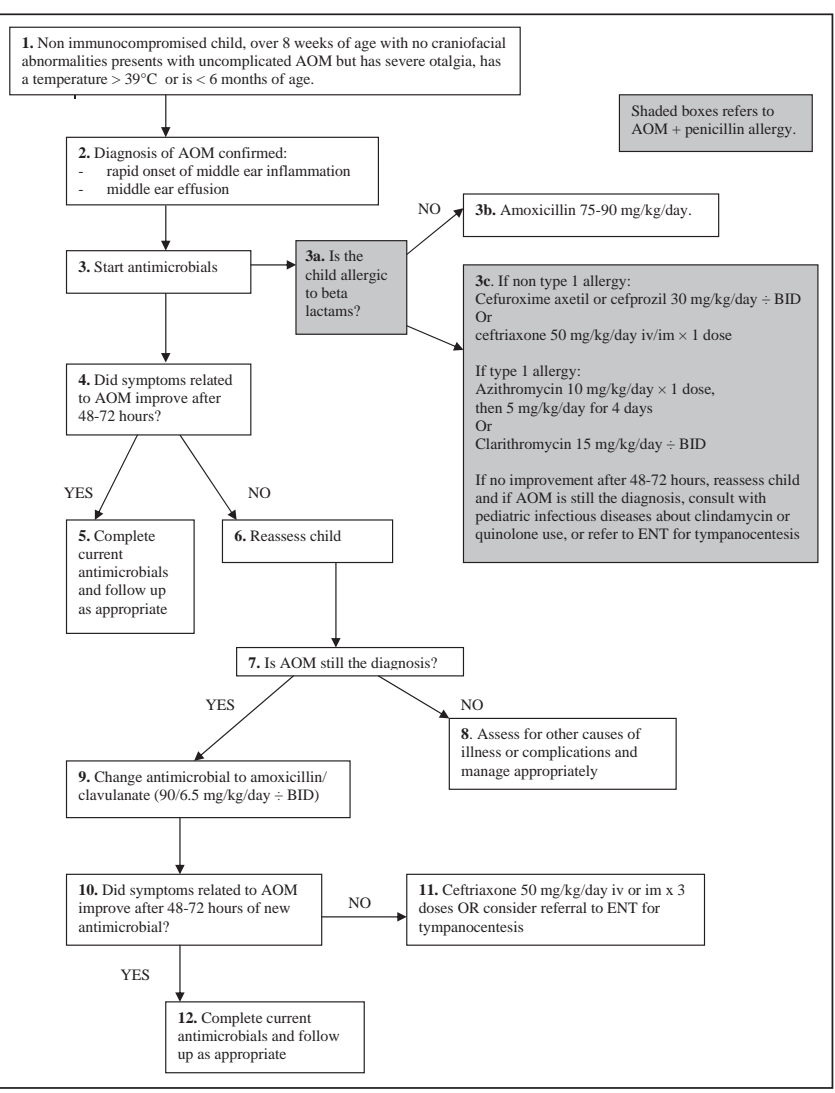

Figure 2) Flow chart for antimicrobial treatment of acute otitis media (AOM) (doses should never exceed the adult dose). BID Twice per day; ENT Ear, nose and throat; im Intramuscular; iv Intravenous

\section{WHAT ARE THE RISKS OF COMPLICATIONS IF ANTIMICROBIALS ARE DEFERRED OR NOT PRESCRIBED FOR AOM?}

It seems intuitive that the early use of antimicrobials will reduce the incidence of serious complications of AOM, such as mastoiditis, meningitis and intracranial abscesses. In the Netherlands, where antimicrobial prescription rates for AOM are approximately $30 \%$, the incidence of paediatric mastoiditis was approximately double the incidence in countries where prescription rates were greater than $90 \%$ (46). Nonetheless, given the rarity of mastoiditis, the authors calculated that at least 2500 prescriptions would have to be filled to prevent one case. They also point out that only approximately $25 \%$ of mastoiditis cases require a mastoidectomy, and that approximately one-half of children with mastoiditis develop this complication despite previously taking antimicrobials for AOM (47). There are no comparable studies for other severe suppurative complications of AOM, but again, it seems likely that thousands of children would have to be treated to prevent one complication.

There are also risks associated with the use of antimicrobials. Approximately $20 \%$ of children develop diarrhea, with complications such as Stevens-Johnson syndrome or anaphylaxis being very rare but sometimes life-threatening. In addition, the development of antibiotic-resistant organisms is primarily driven by the over-use of antibiotics.
TABLE 3

Antimicrobial agents for acute otitis media (AOM)*

First-line treatment (no penicillin allergy):

- Amoxicillin - $75 \mathrm{mg} / \mathrm{kg} /$ day to $90 \mathrm{mg} / \mathrm{kg} /$ day divided twice per day ${ }^{\dagger}$ Second-line treatment:

- Cefprozil - $30 \mathrm{mg} / \mathrm{kg} /$ day divided twice per day

- Cefuroxime axetil - $30 \mathrm{mg} / \mathrm{kg} /$ day divided twice per day

- Ceftriaxone - $50 \mathrm{mg} / \mathrm{kg}$ intramuscularly (or intravenously) x 1 dose

- Azithromycin - $10 \mathrm{mg} / \mathrm{kg}$ once per day $\times 1$ dose, then $5 \mathrm{mg} / \mathrm{kg}$ once per day $x 4$ doses

- Clarithromycin - $15 \mathrm{mg} / \mathrm{kg} /$ day divided twice per day

If initial therapy fails (ie, no symptomatic improvement after two to three days):

- Amoxicillin-clavulanate - $90 \mathrm{mg} / \mathrm{kg} /$ day amoxicillin, $6.4 \mathrm{mg} / \mathrm{kg} / \mathrm{day}$ clavulanate divided twice per day for 10 days $^{\dagger \ddagger}$

- If AOM-related symptoms do not resolve with amoxicillin/clavulanate, a course of ceftriaxone $50 \mathrm{mg} / \mathrm{kg} /$ day intramuscularly (or intravenously) once per day $x 3$ doses could be considered. Alternatively, a referral to otolaryngology for tympanocentesis may be considered to determine the etiological agent and guide therapy

*See text for comments on duration. Adult dose should never be exceeded; ${ }^{\dagger}$ This is a higher dose than usual, chosen to increase the likelihood of eradicating penicillin-resistant pneumococci. If lower doses are used, traditional three times daily dosing is more appropriate. Some experts also recommend three times daily dosing for the higher dose range; ${ }^{\ddagger}$ See Table 4 for amoxicillin plus amoxicillin-clavulanate dosing options

\section{HOW DOES RESISTANCE AFFECT THE CHOICE OF AN ANTIMICROBIAL?}

$S$ pneumoniae antimicrobial resistance is an issue in Canada and around the world. Furthermore, AOM caused by $S$ pneumoniae is the least likely to spontaneously resolve (only $20 \%$ of cases spontaneously resolve versus $50 \%$ with $H$ influenzae) (48). In some cases, it is possible to identify children at risk for infections with antimicrobial resistant $S$ pneumoniae (49). Risk factors include children younger than two years of age, who attend daycare (defined as greater than $4 \mathrm{~h}$ per week with at least two unrelated children), who have frequent otitis media and/or recent antimicrobial use (within the past three months), or who have failed initial antimicrobial therapy for AOM.

Other organisms associated with AOM include $\mathrm{H}$ influenzae and M catarrhalis. Almost all M catarrhalis isolates and approximately one-quarter of $\mathrm{H}$ influenzae produce betalactamases (50). Some beta-lactam antimicrobials are still effective against these organisms, including second- and third-generation cephalosporins and amoxicillin with a beta-lactamase inhibitor (such as clavulanate) added. The activity of clarithromycin or azithromycin is unaffected by the presence of beta-lactamase production.

\section{WHAT IS THE FIRST-CHOICE ANTIMICROBIAL AGENT FOR AOM?}

First-line therapy in a child with no beta-lactam allergies is amoxicillin (Figure 2). No other oral antimicrobial has been shown to have superior efficacy for AOM in a randomized trial. This drug has excellent middle ear penetration (which may be effective despite in vitro resistance), is inexpensive 


\begin{tabular}{|c|c|c|}
\hline Drug & $\begin{array}{l}\text { Dose of amoxicillin } \\
\text { from amoxicillin- } \\
\text { clavulanate }\end{array}$ & $\begin{array}{l}\text { Dose of amoxicillin } \\
\text { to add }\end{array}$ \\
\hline $\begin{array}{l}\text { Clavulin-125F suspension, } \\
\text { Clavulin-250F suspension, } \\
\text { Apo-Amoxi Clav } 125 \mathrm{mg} \\
\text { suspension, Apo-Amoxi Clav } \\
250 \mathrm{mg} \text { suspension, Clavulin- } \\
500 \mathrm{~F} \text { tablets or Apo-Amoxi } \\
\text { Clav } 500 \mathrm{mg} \text { tablets } \\
\text { (4:1 formulations) }\end{array}$ & 25 mg/kg/day & 65 mg/kg/day \\
\hline $\begin{array}{l}\text { Clavulin } 200 \text { suspension or } \\
\text { Clavulin } 400 \text { suspension, } \\
\text { Clavulin } 875 \text { mg tablet or Apo- } \\
\text { Amoxi Clav } 875 \mathrm{mg} \text { tablet } \\
\text { (7:1 formulations) }\end{array}$ & 45 mg/kg/day & $45 \mathrm{mg} / \mathrm{kg} / \mathrm{day}$ \\
\hline $\begin{array}{l}\text { Clavulin } 250 \text { tablet or Apo- } \\
\text { Amoxi Clav } 250 \mathrm{mg} \text { tablet } \\
\text { (2:1 formulations) }\end{array}$ & $12.5 \mathrm{mg} / \mathrm{kg} / \mathrm{day}$ & $77.5 \mathrm{mg} / \mathrm{kg} / \mathrm{day}$ \\
\hline $\begin{array}{l}\text { 14:1 formulations (not yet } \\
\text { licensed in Canada) }\end{array}$ & 90 mg/kg/day & None \\
\hline
\end{tabular}

and well tolerated, and has a relatively narrow antimicrobial spectrum (51). Given in an adequate dose, it is the oral drug that is most likely to be effective against penicillin-resistant $S$ pneumoniae. Because it is not always apparent whether a child has risk factors for resistant $S$ pneumoniae, we recommend that physicians treat with high-dose amoxicillin at $75 \mathrm{mg} / \mathrm{kg} / \mathrm{day}$ to $90 \mathrm{mg} / \mathrm{kg} / \mathrm{day}$. At this dose, the drug will be effective against penicillin-intermediate strains and possibly even high-level penicillin-resistant strains.

If the child has had a type 1 hypersensitivity reaction to amoxicillin or to another beta-lactam antimicrobial (urticaria and/or systemic anaphylaxis), then use of a macrolide (clarithromycin or azithromycin) is an option. If the previous reaction to amoxicillin is not type 1 , second-generation cephalosporins are appropriate choices (Table 3) (52). If the child has had a type 1 hypersensitivity reaction to a betalactam antimicrobial and has failed macrolides, clindamycin or a quinolone should be considered in consultation with an infectious diseases physician. Alternatively, a referral to otolaryngology for tympanocentesis may be considered to determine the etiological agent and to guide therapy (53).

\section{IF SYMPTOMS DO NOT RESOLVE, SHOULD THE ANTIMICROBIAL BE CHANGED?}

Symptoms should improve within one to two days and resolve within two to three days of starting antimicrobials. Middle ear effusions, on the other hand, may persist for months, despite clinical and bacteriological resolution. Therefore, the presence of middle ear effusion does not necessitate a change in antimicrobials. However, if symptoms have not improved after two days, the antimicrobial should be changed to one that targets both penicillinresistant $S$ pneumoniae and beta-lactamase-producing organisms - two choices are amoxicillin/clavulanate or parenteral ceftriaxone (Table 3) (54).

Amoxicillin/clavulanate should be calculated at $90 \mathrm{mg} / \mathrm{kg} /$ day of the amoxicillin component and $6.4 \mathrm{mg} / \mathrm{kg} /$ day of the clavulanate component divided into two doses. Methods for achieving this dose, which require combining amoxicillin/clavulanate with amoxicillin, are shown in Table 4. A 14:1 preparation of amoxicillin/clavulanate is licensed in the United States, allowing for the use of a single medication, but it is not yet available in Canada (55).

\section{WHAT IS AN APPROPRIATE DURATION OF ANTIMICROBIAL THERAPY FOR AOM?}

Five days of antimicrobial treatment with amoxicillin or second-generation cephalosporins are at least as effective as 10 days of therapy in children older than two years of age with uncomplicated $\mathrm{AOM}(56,57)$.

\section{DO SOME CHILDREN WARRANT A 10-DAY COURSE OF THERAPY FOR AOM?}

Ten-day antimicrobial treatment courses are appropriate for children younger than two years of age, children with frequent recurrent $\mathrm{AOM}$ or otitis media with perforated tympanic membrane, and in children who failed their initial antimicrobial, because these children are at increased risk of treatment failure (exceptions to this rule are azithromycin for which a five-day course is the maximum, and ceftriaxone for which one dose is usually given for uncomplicated cases and three doses for cases that failed initial therapy) (58-65). The benefit of the longer course may partly come from the child being in a 'prophylaxed' state should he or she develop a new upper respiratory tract infection within 10 days of AOM diagnosis. However, should the child develop antimicrobial-related adverse events between day 5 and day 10, it is reasonable to stop antimicrobials rather than prescribing an alternative antimicrobial.

\section{WHAT CAN PARENTS DO TO REDUCE THEIR CHILD'S RISK OF DEVELOPING AOM?}

Parents can reduce their child's risk for AOM by implementing practices that reduce the chances of contracting viral respiratory tract infections or by preventing other factors that promote inflammation of the eustachian tube:

- Following simple hygienic practices such as hand hygiene (after handling respiratory secretions, nasal discharge or used tissues) with regular soap or alcohol-based hand sanitizer can have a positive impact on the health of families in nonmedical settings (66).

- Exclusive breastfeeding until at least three months of age reduces the incidence of $\mathrm{AOM}$, and this effect persists four to 12 months after breastfeeding ceases (67-69). This reduction is likely to be secondary to immunoglobulins and other components in breast milk that increase infants' immunity to pathogens (70). This reduction may also be secondary to the absence of bottle-feeding. When a baby 
is bottlefed (especially if the bottle is propped), negative pressure inside the bottle causes the infant to suck excessively and generate negative pressure within the eustachian tube, setting the stage for AOM. This does not occur with breastfeeding, or with the use of fully ventilated bottles (71).

- Pacifier use in children younger than three years of age increases the risk for recurrent otitis media by up to $25 \%$. The risk appears to be related to the frequency of use $(72,73)$.

- Limiting daycare exposure for very young children decreases the risk of upper respiratory tract infection and, therefore, AOM. The risk correlates with the number of contacts with other children rather than the absolute number of children enrolled in the centre, and the risk is highest in the first year of life (74).

- Encourage childcare providers to develop and implement procedures for hand hygiene, as well as toy and environmental cleaning. In a study (75) involving 60 childcare centres where hand hygiene, environmental cleaning, and increased washing of toys and linens was emphasized, there was a $26 \%$ reduction in upper respiratory tract infections in children younger than three years of age.

- Not smoking. Maternal smoking during the first year of life is a significant risk factor for recurrent otitis media, especially in low birth weight infants (76).

\section{WHICH VACCINES WILL OFFER PROTECTION AGAINST AOM?}

Use of the influenza vaccine is highly encouraged for healthy children older than six months of age and for their parents and caregivers (77-79). Influenza plays an important role in the pathogenesis of $\mathrm{AOM}$, and the killed influenza vaccine has been shown to provide some protection against AOM in toddlers (80-82). Although not yet available in Canada, the live attenuated intranasal vaccine showed high efficacy (94\% to $98 \%$ ) in preventing influenza-associated AOM in children 15 to 71 months of age $(83,84)$.

The pneumococcal conjugate vaccine is part of the routine schedule for all Canadian children. This vaccine has limited efficacy against AOM because only seven pneumococcal serotypes are contained in the current vaccine, and there is increasing evidence of 'replacement disease' with nonvaccine serotypes $(85,86)$. Preliminary studies of upcoming conjugated pneumococcal vaccines show a greater effect against AOM. They contain more pneumococcal serotypes and some are conjugated to carriers such as protein $\mathrm{D}$ from $H$ influenzae and, thus, are efficacious in preventing AOM from pneumococci and nontypeable $H$ influenzae $(87,88)$.

\section{RECOMMENDATIONS}

The levels of evidence reported in the recommendations have been described using the evaluation of evidence criteria outlined by the Canadian Task Force on Preventive Health Care (89).
- To properly diagnose AOM, there must be signs of a middle ear effusion, middle ear inflammation and an acute onset of symptoms. Signs of a middle ear effusion may include a tympanic membrane that is immobile with or without opacification, loss of bony landmarks, or a tympanic membrane that has ruptured with fluid in the external ear canal. Signs of middle ear inflammation include a tympanic membrane that is bulging and discoloured. Symptoms of AOM include rapid onset of ear pain or unexplained irritability in a preverbal child (AII-2).

- For otherwise healthy children older than six months of age with no craniofacial abnormalities who have mild clinical signs and symptoms, a watchful waiting approach for $48 \mathrm{~h}$ to $72 \mathrm{~h}$ is an option if follow-up can be assured (BI). Advice regarding analgesics must be provided. It is recommended to either have the family return if the child does not improve or to provide a prescription for antimicrobials that they can fill at their own discretion (deferred prescription)

- If a decision is made to treat with antimicrobials, highdose amoxicillin ( $75 \mathrm{mg} / \mathrm{kg} /$ day to $90 \mathrm{mg} / \mathrm{kg} /$ day $)$ is the first choice for AOM therapy (AI/AII). A five-day course is appropriate for most children older than two years of age, with a 10-day course being reserved for younger children (AI) or those with complicated or frequently recurrent AOM (AIII).

- Parents should be educated about the factors that may increase the risk of AOM in their children (BII-III).

- The influenza vaccine (AII) and pneumococcal conjugate vaccine $(\mathrm{AI})$ should be offered to all children of appropriate age.

\section{REFERENCES}

1. Canadian Paediatric Society, Infectious Diseases and Immunization Committee. [Principal author: D Speert]. Antibiotic management of acute otitis media. Paediatr Child Health 1998;3:265-7.

2. Faden H, Duffy L, Boeve M. Otitis media: Back to the basics. Pediatr Inf Dis J 1998;17:1105-12.

3. Kemp ED. Otitis media. Prim Care 1990;17:267-87.

4. Zielhuis GA, Rach GH, van den Broek P. Predisposing factors for otitis media with effusion in young children. Adv Otorhinolaryngol 1988;40:65-9.

5. Chonmaitree T, Revai K, Grady JJ, et al. Viral upper respiratory tract infection and otitis media complication in young children. Clin Infect Dis 2008;46:815-23.

6. Alper CM, Winther B, Mandel EM, Doyle WJ. Temporal relationships for cold-like illnesses and otitis media in sibling pairs. Pediatr Infect Dis J 2007;26:778-81.

7. Kurono Y, Mogi G. Otitis media with effusion and the nasopharynx. A bacteriological and immunological study. Acta Otolaryngol Suppl 1988;454:214-7.

8. Winther B, Hayden FG, Arruda E, Dutkowski R, Ward P, Hendley JO. Viral respiratory infection in schoolchildren: Effects on middle ear pressure. Pediatrics 2002;109:826-32.

9. Birch L, Elbrønd O. A prospective epidemiological study of secretory otitis media in young children related to the indoor environment. ORL J Otorhinolaryngol Relat Spec 1987;49:253-8.

10. Chonmaitree T, Owen MJ, Patel JA, Hedgpeth D, Horlick D, Howie VM. Effect of viral respiratory tract infection on outcome of acute otitis media. J Pediatr 1992;120:856-62.

11. Bowd AD. Otitis media: Health and social consequences for aboriginal youth in Canada's north. Int J Circumpolar Health 2005;64:5-15. 
12. Roddey OF Jr, Earle R Jr, Haggerty R. Myringotomy in acute otitis media. A controlled study. JAMA 1966;197:849-53.

13. Roddey OF, Hoover HA. Otitis media with effusion in children: A pediatric office perspective. Pediatr Ann 2000;29:623-9.

14. Schwartz RH, Stool SE, Rodriguez WJ, Grundfast KM. Acute otitis media: Toward a more precise definition. Clin Pediatr (Phila) 1981;20:549-54.

15. Leibovitz E, Greenberg D, Piglansky L, et al. Recurrent acute otitis media occurring within one month from completion of antibiotic therapy: Relationship to the original pathogen. Pediatr Infect Dis J 2003;22:209-16.

16. Chan LS, Takata GS, Shekelle P, Morton SC, Mason W, Marcy SM. Evidence assessment of management of acute otitis media: II. Research gaps and priorities for future research. Pediatrics 2001;108:248-54

17. Kaleida PH. The COMPLETES exam for otitis. Contemp Pediatr 1997;14:93-101.

18. Karma PH, Penttila MA, Sipila MM, Kataja MJ. Otoscopic diagnosis of middle ear effusion in acute and non-acute otitis media The value of different otoscopic findings. Int J Pediatr Otolaryngol 1989;17:37-49.

19. Pelton SI. Otoscopy for the diagnosis of otitis media. Pediatr Inf Dis J 1998;17:540-3.

20. Dowell SF, Marcy SM, Phillips WR, Gerber MA, Schwartz B. Otitis media - principles of judicious use of antimicrobial agents. Pediatrics 1998;101(Suppl):165-71.

21. Kaleida PH, Stool SE. Assessment of otoscopists' accuracy regarding middle-ear effusion. Ostoscopic validation. Am J Dis Child 1992;146:433-5.

22. Silva $A B$, Hotaling AJ. A protocol for otolarngology-head and neck resident training in pneumatic otoscopy. Int J Pediatr Otorhinolaryngol 1997;40:125-31.

23. Heikkinen T, Thint M, Chonmaitree T. Prevalence of various respiratory viruses in the middle ear during acute otitis media. N Engl J Med 1999;340:260-4.

24. Ruuskanen $\mathrm{O}$, Heikkinen T. Viral-bacterial interaction in acute otitis media. Pediatr Infect Dis J 1994;13:1047-9.

25. Ruuskanen O, Arola M, Heikkinen T, Ziegler T. Viruses in acute otitis media: Increasing evidence for clinical significance. Pediatr Infect Dis J 1991;10:425-7.

26. Pichichero ME. Evolving shifts in otitis media pathogens: Relevance to a managed care organization. Am J Manag Care 2005;11:S192-201.

27. Giebink GS. The microbiology of otitis media. Pediatr Infect Dis J 1989;8:S18-20.

28. Bluestone CD, Stephenson JS, Martin LM. Ten-year review of otitis media pathogens. Pediatr Infect Dis J 1992;11:S7-11.

29. Block SL, Hedrick J, Harrison CJ, et al. Community-wide vaccination with the heptavalent pneumococcal conjugate significantly alters the microbiology of acute otitis media. Pediatr Infect Dis J 2004;23:829-33.

30. Casey JR, Pichichero ME. Changes in frequency and pathogens causing acute otitis media in 1995-2003. Pediatr Infect Dis J 2004;23:824-8.

31. Brunton S. Current face of acute otitis media: Microbiology and prevalence resulting from widespread use of heptavalent pneumococcal conjugate vaccine. Clin Ther 2006;28:118-23.

32. Rosenfeld RM, Vertrees JE, Carr J, et al. Clinical efficacy of antimicrobial drugs for acute otitis media: Metaanalysis of 5400 children from thirty-three randomized trials. J Pediatr 1994;124:355-67.

33. Takata GS, Chan LS, Shekelle P, Morton SC, Mason W, Marcy SM. Evidence assessment of management of acute otitis media: I. The role of antimicrobials in treatment of uncomplicated acute otitis media. Pediatrics 2001;108:239-47.

34. Glasziou PP, Delmar CB, Sanders SL, Hayem M. Antibiotics for acute otitis media in children. Cochrane Database Syst Rev 2004:CD000219.

35. Dagan R, McCracken GH Jr. Flaws in design and conduct of clinical trials of acute otitis media. Pediatr Infect Dis J 2002;21:894-902.

36. Marchant CD. Acute otitis media, antibiotics, children and clinical trial design. Pediatr Infect Dis J 2002;21:891-3.

37. Asher E, Dagan R, Greenberg D, et al. Persistence of pathogens despite clinical improvement in antibiotic-treated acute otitis media is associated with clinical and bacteriologic relapse. Pediatr Infect Dis J 2008;27:296-301.
38. Finkelstein JA, Stille CJ, Rifas-Shiman SL, Goldmann D. Watchful waiting for acute otitis media: Are parents and physicians ready? Pediatrics 2005;115:1466-73.

39. Siegel RM, Kiely M, Bien JP, et al. Treatment of otitis media with observation and a safety-net antibiotic prescription. Pediatrics 2003;112:527-31.

40. Appleman CLM, van Balen FAM, van de Lisdonk EH, van Weert HCPM, Eizenga WH. Otitis media acuta. NHGstandaard (eerste herziening). Huisarts Wet 1999;42:362-366.

41. American Academy of Pediatrics Subcommittee on Management of Acute Otitis Media. Diagnosis and management of acute otitis media. Pediatrics 2004;113:1451-65.

42. Little P, Gould C, Williamson I, Moore M, Warner G, Dunleavey J. Pragmatic randomised controlled trial of two prescribing strategies for childhood acute otitis media. BMJ 2001;322:336-42.

43. McCormick DP, Chonmaitree T, Pittman C, et al. Nonsevere acute otitis media: A clinical trial comparing outcomes of watchful waiting versus immediate antibiotic treatment. Pediatrics 2005;115:1455-65.

44. Kaleida PH, Blatter MM, Reisinger KS, et al. Amoxicillin or myringotomy or both for acute otitis media: Results of a randomized clinical trial. Pediatrics 1991;87:466-74.

45. Morris PS, Leach AJ, Halpin S, et al. An overview of acute otitis media in Australian Aboriginal children living in remote communities. Vaccine 2007;25:2389-93.

46. Van Zuijlen DA, Schilder AG, Van Balen FA, Hoes AW. National differences in incidence of acute mastoiditis: Relationship to prescribing patterns of antibiotics for acute otitis media? Pediatr Infect Dis J 2001;20:140-4.

47. Hoppe JE. Antibiotics and mastoiditis. Pediatr Infect Dis J 2001;20:1012-3

48. Klein JO. Clinical implications of antibiotic resistance for management of acute otitis media. Pediatr Infect Dis J 1998;17:1084-9.

49. Levine OS, Farley M, Harrison LH, Lefkowitz L, McGeer A, Schwartz B. Risk factors for invasive pneumococcal disease in children: A population-based case-control study in North America. Pediatrics 1999;103:E28

50. Zhanel GG, Palatnick L, Nichol KA, Low DE, Hoban DJ, The CROSS Study Group. Anitmicrobial resistance in Haemophilus influenzae and Moraxella catarrhalis respiratory tract isolates: Results of the Canadian Respiratory Organism Susceptibility Study, 1997-2002. Antimicrob Agents Chemother 2003;47:1875-81

51. Dowell SF, Butler JC, Giebink GS, et al. Acute otitis media: Management and surveillance in an era of pneumococcal resistance - a report from the Drug-resistant Streptococcus pneumoniae Therapeutic Working Group. Pediatr Infect Dis J 1999;18:1-9.

52. Hedrick JA, Sher LD, Schwartz RH, Pierce P. Cefprozil versus highdose amoxicillin/clavulanate in children with acute otitis media. Clin Ther 2001;23:193-204.

53. Pichichero ME. Acute otitis media: Part II. Treatment in an era of increasing antibiotic resistance. Am Fam Physician 2000;61:2410-6.

54. Hoberman A, Marchant CD, Kaplan SL, Feldman S. Treatment of acute otitis media consensus recommendations. Clin Pediatr (Phila) 2002;41:373-90.

55. Easton J, Noble S, Perry CM. Amoxicillin/clavulanic acid: A review of its use in the management of pediatric patients with acute otitis media. Drugs 2003;63:311-40.

56. Kafetzis DA, Astra H, Mitropoulos L. Five-day versus ten-day treatment of acute otitis media with cefprozil. Eur J Clin Microbiol Infect Dis 1997;16:283-6.

57. Kozyrskyj AL, Hildes-Ripstein GE, Longstaffe SE, et al. Treatment of acute otitis media with a shortened course of antimicrobials: A meta-analysis. JAMA 1998;279:1736-42.

58. Hathaway TJ, Katz HP, Dershewitz RA, Marx TJ. Acute otitis media: Who needs posttreatment follow-up? Pediatrics 1994:94:143-7.

59. Cohen R, Levy C, Boucherat M, Langue J, de la Roque F. A multicenter, randomized, double blind trial of 5 versus 10 days of antibiotic therapy for acute otitis media in young children. J Pediatr 1998;133:634-9.

60. Hendrickse WA, Kusmiesz H, Shelton S, Nelson JD. Five vs. ten days of therapy for acute otitis media. Pediatr Infect Dis J $1988 ; 7: 14-23$. 
61. Damoiseaux RA, van Balen FA, Hoes AW, Verheij TJ, de Melker RA. Primary care based randomised, double blind trial of amoxicillin versus placebo for acute otitis media in children aged under 2 years. BMJ 2000;320:350-4.

62. Ovetchkine P, Cohen R. Shortened course of antimicrobial therapy for acute otitis media. Paediatr Drugs 2003;5:133-40.

63. Cohen R, Levy C, Boucherat M, et al. Five vs. ten days of antibiotic therapy for acute otitis media in young children. Pediatri Infect Dis J 2000;19:458-63.

64. Paradise JL. Short-course antimicrobial treatment for acute otitis media: Not best for infants and young children. JAMA 1997;278:1640-2.

65. Pichichero ME, Marsocci SM, Murphy ML, Hoeger W, Francis AB, Green JL. A prospective observational study of 5-, 7-, and 10-day antibiotic treatment for acute otitis media. Otolaryngol Head Neck Surg 2001;124:381-7.

66. Larson EL, Lin SX, Gomez-Pichardo C, Della-Latta P. Effect of antibacterial home cleaning and handwashing products on infectious disease symptoms: A randomized, double-blind trial. Ann Intern Med 2004;140:321-9.

67. Aniansson G, Alm B, Andersson B, et al. A prospective cohort study on breast-feeding and otitis media in Swedish infants. Pediatr Infect Dis J 1994;13:183-8.

68. Duncan B, Ey J, Holberg CJ, Wright AL, Martinez FD, Taussig LM. Exclusive breast-feeding for at least 4 months protects against otitis media. Pediatrics 1993;91:867-72.

69. Duffy LC, Faden H, Wasielewski R, Wolf J, Krystofik D. Exclusive breastfeeding protects against bacterial colonization and day care exposure to otitis media. Pediatrics 1997;100:E7.

70. Waseem M, Aslam M, Wilson L. Otitis media. eMedicine, 2008. $<$ http://www.emedicine.com/ped/topic1689.htm> (Version current at July 23, 2009).

71. Brown CE, Magnuson B. On the physics of the infant feeding bottle and middle ear sequela: Ear disease in infants can be associated with bottle-feeding. Int J Pediatr Otorhinolaryngol 2000;54:13-20.

72. Hanafin S, Griffiths P. Does pacifier use cause ear infections in young children? Br J Community Nurs 2002;7:206-11.

73. Niemelä M, Uhari M, Möttönen M. A pacifier increases the risk of recurrent acute otitis media in children in day care centers. Pediatrics 1995;96:884-8.

74. Owen MJ, Baldwin CD, Swank PR, Pannu AK, Johnson DL, Howie VM. Relation of infant feeding practices, cigarette smoke exposure, and group child care to the onset and duration of otitis media with effusion in the first two years of life. J Pediatr 1993;123:702-11.

75. Pönkä A, Poussa T, Laosmaa M. The effect of enhanced hygiene practices on absences due to infectious diseases among children in daycare centers in Helsinki. Infection 2004;32:2-7.
76. Ey JL, Holberg CJ, Aldous MB, Wright AL, Martinez FD, Taussig LM. Passive smoke exposure and otitis media in the first year of life. Group Health Medical Associates. Pediatrics 1995;95:670-7.

77. Public Health Agency of Canada. Canadian Immunization Guide, Seventh Edition - 2006. <http://www.phac-aspc.gc.ca/publicat/ciggci/index-eng.php> (Version current at July 23, 2009).

78. National Advisory Committee on Immunization. Statement on Influenza Vaccination for the 2008-2009 Season. CCDR 2008;34:ACS-3.

79. American Academy of Pediatrics, Committee on Infectious Diseases. Reduction of the influenza burden in children. Pediatrics 2002;110:1246-52.

80. Heikkinen T, Ruuskanen O, Waris M, Ziegler T, Arola M, Halonen P. Influenza vaccination in the prevention of acute otitis media in children. Am J Dis Child 1991;145:445-8.

81. Clements DA, Langdon L, Bland C, Walter E. Influenza A vaccine decreases the incidence of otitis media in 6-to 30-month-old children in day care. Arch Pediatr Adolesc Med 1995;149:1113-7.

82. Hoberman A, Greenberg DP, Paradise JL, et al. Effectiveness of inactivated influenza vaccine in preventing acute otitis media in young children: A randomized controlled trial. JAMA 2003;290:1608-16.

83. Belshe RB, Gruber WC. Safety, efficacy and effectiveness of coldadapted, live, attenuated, trivalent, intranasal influenza vaccine in adults and children. Philos Trans R Soc Lond B Biol Sci 2001;356:1947-51.

84. Belshe RB, Gruber WC. Prevention of otitis media in children with live attenuated influenza vaccine given intranasally. Pediatr Infect Dis J 2000;19:S66-71.

85. Brouwer CN, Maillé AR, Rovers MM, et al. Effect of pneumococcal vaccination on quality of life in children with recurrent acute otitis media: A randomized, controlled trial. Pediatrics 2005;115:273-9.

86. Straetemans M, Sanders EA, Veenhoven RH, Schilder AG, Damoiseaux RA, Zielhuis GA. Pneumococcal vaccines for preventing otitis media. Cochrane Database Syst Rev 2004:CD001480

87. Prymula R, Chlibek R, Splino M, et al. Safety of the 11-valent pneumococcal vaccine conjugated to non-typeable Haemophilus influenzae-derived protein D in the first 2 years of life and immunogenicity of the co-administered hexavalent diphtheria, tetanus, acellular pertussis, hepatitis B, inactivated polio virus, Haemophilus influenzae type $\mathrm{B}$ and control hepatitis $\mathrm{A}$ vaccines. Vaccine 2008;26:4563-70.

88. Bernatoniene J, Finn A. Advances in pneumococcal vaccines: Advantages for infants and children. Drugs 2005;65:229-55.

89. Canadian Task Force on Preventive Health Care. New grades for recommendations from the Canadian Task Force on Preventive Health Care. CMAJ 2003;169:207-8. <http://www.ctfphc.org/ ctfphc\&methods.htm\#Methods> (Version current at July 23, 2009).

\section{INFECTIOUS DISEASES AND IMMUNIZATION COMMITTEE}

Members: Drs Robert Bortolussi, IWK Health Centre, Halifax, Nova Scotia (Chair); Jane Finlay, Richmond, British Columbia; Joan L Robinson, Edmonton, Alberta; Élisabeth Rousseau-Harsany, Sainte-Justine UHC, Montreal, Quebec (Board Representative); Lindy M Samson, Children's Hospital of Eastern Ontario, Ottawa, Ontario

Consultants: Drs Noni E MacDonald, IWK Health Centre, Halifax, Nova Scotia; Dorothy L Moore, The Montreal Children's Hospital, Montreal, Quebec

Liaisons: Drs Upton D Allen, The Hospital for Sick Children, Toronto, Ontario (Canadian Pediatric AIDS Research Group); Charles PS Hui, Children's Hospital of Eastern Ontario, Ottawa, Ontario (CPS Liaison to Health Canada, Committee to Advise on Tropical Medicine and Travel); Nicole Le Saux, Children's Hospital of Eastern Ontario, Ottawa, Ontario (Immunization Program, ACTive); Larry Pickering, Elk Grove, Illinois, USA (American Academy of Pediatrics); Marina I Salvadori, Children's Hospital of Western Ontario, Ottawa, Ontario (CPS Liaison to Health Canada, National Advisory Committee on Immunization)

Principal authors: Drs Sarah ED Forgie, University of Alberta, Edmonton, Alberta; George Zhanel; University of Manitoba, Winnipeg, Manitoba; Joan L Robinson, Edmonton, Alberta

The recommendations in this statement do not indicate an exclusive course of treatment or procedure to be followed. Variations, taking into account individual circumstances, may be appropriate.

All Canadian Paediatric Society position statements/notes are reviewed, revised or retired as needed on a regular basis.

For the most current version, please consult the "Position Statements" section

of the CPS website (www.cps.ca/english/publications/statementsindex.htm). 